\title{
Hubungan antara Keterampilan Evaluasi dengan Keterlaksanaan Evaluasi Program BK di SMA Se- Kecamatan Cilinci Jakarta Utara
}

\author{
Khairunisa ${ }^{1}$, Ariyana Rustam ${ }^{2}$, Ihsan Nurkholis ${ }^{3}$, Anaway Irianti Mansyur ${ }^{4}$, \\ Maslikhah $^{5}$, Aip Badrujaman ${ }^{6}$ \\ Universitas Negeri Jakarta ${ }^{1,2,3,4,5, \& 6}$ \\ Email: khairunisa_bk18s2@mahasiswa.unj.ac.id ${ }^{1}$, \\ ariyanarustam_bk18s2@mahasiswa.unj.ac.id ${ }^{2}$, \\ ihsannurkholis_bk18s2@mahasiswa.unj.ac.id ${ }^{3}$, \\ anawayirianti_bk18s2@mahasiswa.unj.ac.id ${ }^{4}$ \\ maslikhah_bk18s2@mahasiswa.unj.ac.id ${ }^{5}$,aip_bj@yahoo.com ${ }^{6}$
}

\begin{abstract}
:
This study aims to determine the relationship between evaluation skills and the implementation of a guidance and counseling program evaluation in Cilincing North Jakarta Sub-District High School. This research uses quantitative research using survey methods. The collection technique used in this study is a Guttman scale questionnaire and the data analysis technique used in this study is the Product Moment Correlation. This research was conducted in North Jakarta with the subjects of high school teachers in Cilincing Sub-District, North Jakarta City, 30 teachers were divided into 7 Public High Schools and 4 Private High Schools. The results of this study indicate the correlation coefficient between evaluation skills $(X)$ with program evaluation exercise $(Y) r_{-} x y=0.64>$ rtabel $=0.36$, which means that there is a positive relationship between evaluation skills and the implementation of school guidance and counseling evaluation programs which means if the evaluation skills of the counselor are good, the better the evaluation of the guidance and counseling program at the school.
\end{abstract}

Keyword: evaluation skills, correlation, counseling

Received August 25, 2019; Revised September 15, 2019; Accepted October 1, 2019

How to Cite: Khairunisa, Rustam A., Nurkholis I., Mansyur A. I., Maslikhah, Badrujaman A. (2019). Hubungan antara Keterampilan Evaluasi dengan Keterlaksanaan Evaluasi Program BK di SMA Se-Kecamatan Cilinci Jakarta Utara. JKI (Jurnal Konseling Indonesia), 5(1), 21-27.

\section{PENDAHULUAN}

Bimbingan konseling komprehensif merupakan program bimbingan konseling yang bertujuan untuk memandirikan peserta didik dengan cara mengembangkan potensi, membantu mengentaskan masalah siswa, dan memenuhi kebutuhan siswa Cobia \& Handerson, 2003; Gysbers \& Handerson, 2006 (Anni, 2011)). Gibson \& Mitchell (2011) dan (Otto, 2001) menyatakan bahwa jantung hati bimbingan dan konseling adalah program 
konseling karena program konseling disusun melalui serangkaian proses sistematis sejak dari perencanaan, desain, implementasi, evaluasi, dan keberlanjutan. Melalui penerapan fungsi-fungsi manajemen tersebut diharapkan kegiatan dan layanan BK dapat diselenggarakan secara tepat sasaran dan terukur. salah satu kegiatan yang harus dilakukan konselor untuk mengukur keberhasilan dan keterlaksanaan suatu program ialah evaluasi (Rahman, 2012). kemudian, hasil evaluasi yang dilaksanakan akan digunakan sebagai dasar untuk memverifikasi kekuatan dan kelemahan program konseling (Putra W. N., 2015).

Evaluasi program bimbingan dan konseling merupakan komponen yang masih lemah dalam penyelenggaraan program bimbingan dan konseling di Indonesia. (Badrujaman, Furqon, Yusuf, \& Suherman, 2011). Evaluasi program biasanya dilakukan untuk kepentingan pengambil kebijakaan untuk menentukan kebijakan selanjutnya. Penentuan kebijakan akan tepat apabila data yang digunakan sebagai dasar pertimbangan tersebut benar, akurat, dan lengkap (Rahman, 2012). Purwanto (2001:3-4) memaparkan bahwa dalam makna evaluasi itu terkandung 3 (tiga) aspek yaitu a. kegiatan evaluasi merupakan proses yang sistematis, terencana dan dilakukan secara berkesinambungan. b. ketika melakukan kegiatan evaluasi diperlukan berbagai informasi atau data yang menyangkut objek yang sedang dievaluasi. Ketepatan keputusan hasil evaluasi sangat bergantung kepada kesahihan dan objektivitas data yang digunakan dalam pengambilan keputusan. c. Setiap kegiatan evaluasi tidak dapat dilepaskan dari tujuan-tujuan yang hendak dicapai. Tanpa menentukan atau merumuskan tujuantujuan terlebih dahulu, tidak mungkin menilai sejauhmana pencapaian hasil. (Ananda \& Ratida, 2017). Akan tetapi, peneliti menemukan beberapa fenomena berbeda dilapangan yakni sebagaian besar konselor sekolah belum melaksanakan program bimbingan komperhensif, konselor sekolah menyelenggarakan program konseling fokus pada pengentasan masalah siswa, konselor sekolah kurang memahami mengenai apa itu bimbingan konseling komperhensif dan hal ini juga membuat mereka tidak memahami mengapa pentingnya melakukan evaluasi pada program dan keterlaksanaan layanan, serta konselor sekolah belum memhaami bagaimana cara melakukan evaluasi komperhensif berkaitand dengan evaluasi program, evaluasi keterlakasanaan layanan, dan evaluasi proses. Bahkan, sebagian konselor mengungkapkan bahwa plekasanaan konseling disekolah mereka sudah baik walaupun tanpa melakukan proses evaluasi. Seharusnya, evaluasi sangat penting dilakukan guna mengukur kesuksesan dan keterlaksanaan program yang telah disusun serta memberikan solusi yang tepat pada masalah-masalah yang terjadi.

Penilaian program Bimbingan Konseling merupakan usaha untuk menilai sejauh mana pelaksanaan program itu mencapai tujuan yang telah ditetapkan. Dengan kata lain bahwa keberhasilan program dalam pencapaian tujuan merupakan suatu kondisi yang hendak dilihat lewat kegiatan penilaian (Faricha Azizah, 2017). Konselor sekolah harus memiliki keterampilan melakukan evaluasi baik diperoleh melalui ilmu pendidikan saat di bangku kuliah ataupun melalui pelatihan. keterampilan ini sangat berguna untuk memajukan profesi bimbingan konseling dan menecagh terjadinya mal-praktik pada konseling. Juga, melalui evaluasi konselor dapat melihat efektiftas dan efesiensi program yang telah disusun, memperbaiki program kerja konseling yag telah disusun, dan meningkatkan akuntabilitas pada pelayanan konseling (Putra \& Nusantoro, 2015).

Keterampilan (skill) merupakan kemampuan untuk mengoperasikan pekerjaan secara mudah dan cermat (Sri Widiastuti, 2010: 49). Sedangkan menurut Hari Amirullah (2003: 17) istilah terampil juga diartikan sebagai suatu perbuatan atau tugas, dan sebagai indikator dari suatu tingkat kemahiran. Evaluasi dapat pula diartikan sebagai proses pengumpulan informasi (data) untuk mengetahui efektifitas(keterlaksanaa dan ketercapaian) kegiatan-kegiatan yang telah dilaksanakan dalam upaya mengambil keputusan. Keterampilan evaluasi adalah kemampuan seseorang dalam mengumpulkan informasi (data) untuk mengetahui efektifitas (keterlaksanaa dan ketercapaian) kegiatan-kegiatan yang telah dilaksanakan dalam upaya mengambil keputusan guna untuk meningkatkan kinerjanya.

Keterlaksanaan yang berasal dari kata dasar laksana yang berarti sifat, laku, tanda yang baik, seperti, sebagai, melaksanakan: memperbandingkan,menyamakan,melakukan: menjalankan, mengerjakan (Kamus Besar Bahasa Indonesia Pusat Bahasa, 2008:774). Sedangkan menurut Poerwadarminta (1976: 553), kata laksana berarti sifat: tanda, laku, perbuatan. Seperti, sebagai. Melaksanakan berarti: memperbandingkan, menyamakan: melakukan, menjalankan, rancangan, mempraktekan (teori dsb) menyampaikan. Keterlaksanaan dalam penelitian disini adalah melihat keterlaksanaan evaluasi program yang dilakukan oleh guru bimbingan konseling dalam evaluasi pencapaian sehingga dapat memunculkan pemahaman kerlaksanaan serta ketrampilan evaluasi program.

Fungsi Evaluasi Kegiatan BK Secara umum, evaluasi kegiatan/ pelaksanaan program bimbingan konseling dapat berfungsi sebagai: (1) Memberi umpan balik (feedback) kepada guru pembimbing untuk memperbaiki atau mengembangkan kegiatan/ pelaksanaan program bimbingan dan konseling. (2) Memberi informasi kepada pihak pimpinan sekolah, guru mata pelajaran, dan orang tua siswa tentang perkembangan sikap dan prilaku, atau tingkat pencapaian tugas-tugas perkembangan siswa, agar secara bersinergi atau berkolaborasi meningkatkan kualitas implementasi program bimbingan dan konseling di sekolah. Mengevaluasi suatu layanan ada tiga tahap yaitu: (a) Evaluasi pelaksanaan" evaluasi yang dilakukan ketika layanan diberikan lebih ditekankan pada 
pelaksanaan mulai dari awal layanan sampai selesai". (b) Evaluasi proses "evaluasi yang dilakukan terhadap proses ketika layanan diberikan lebih identik pada pengamatan partisipasi dan aktivitas siswa/klien disaat layanan diberikan apakah klien/siswa aktif atau fasif. (c) Evaluasi hasil "evaluasi yang dilakukan pada akhir suatu kegiatan atau layanan.

Tahap-tahap Pelaksanaan Program Bimbingan Konseling Pelaksanaan program satuan kegiatan yaitu kegiatan layanan dan kegiatan pendukung yang merupakan ujung tombak kegiatan bimbingan dan konseling secara keseluruhan. Tahap-tahap yang harus ditempuh adalah sebagai berikut: (1) Tahap perencanaan, program satuan satuan layanan dan kegiatan pendukung direncanakan secara tertulis dengan sasaran, tujuan, materi, metode, waktu, tempat, dan rencana penilaian. (2) Tahap pelaksanaan, program tertulis satuan kegiatan (layanan atau pendukung) dilaksanakan sesuai dengan perencanaannya. (3) Tahap penilaian, hasil kegiatan ukur dengan nilai. (4) Tahap analisis hasil, hasil penilaian dianalisis untuk mengetahui aspek-aspek yang perlu mendapat perhatian lebih lanjut. (5) Tahap tindak lanjut, hasil kegiatan yang ditindaklanjuti berdasarkan hasil analisis yang dilakukan sebelumnya melalui layanan dan kegatan pendukung yang relevan.

Langkah-langkah Evaluasi Program Bimbingan Konseling Menurut Mamat Supriatna dalam melaksanakan evaluasi program, ada beberapa hal yang harus ditempuh yaitu sebagai berikut: (1) Merumuskan masalah atau beberapa pertanyaan. Pertanyaan ini menyangkut dengan yang dievaluasi yaitu, (a) tingkat keterlaksanaan program (aspek proses), (b) tingkat ketercapaian tujuan program (hasil). (2) Mengembangkan atau menyusun instrument pengumpul data. Untuk memperoleh data yang diperlukan yaitu mengenai tingkat keterlaksanaan dan ketercapaian program, konselor harus menyusun instrument yang relevan dengan kedua aspek tersebut. Instrument itu diantaranya angket, pedoman wawancara, pedoman observasi, dan studi dokumentasi. (3) Mengumpulkan analisis data. Setelah diperoleh, data harus dianalisis yaitu telaah apa saja yang telah dan belum dilaksanakan, serta tujuan mana saja yang telah dan belum tercapai. (4) Melakukan tindak lanjut (follow up). Berdasarkan temuan yang diperoleh, dapat dilakukan kegiatan tindak lanjut. Kegiatan ini meliputi dua kegiatan yait: (a) memperbaiki hal-hal yang dipandang lemah, kurang tepat atau relevan dengan tujuan yang ingin dicapai dan mengembangkan program dengan cara mengubah atau menambah beberapa hal yang dipandang perlu untuk meningkatkan efektivitas atau kualitas program

Menurut Suharsimi dalam Amirah Program Bimbingan Konseling adalah keseluruhan yang mencakup kegiatan yang dilakukan oleh petugas Bimbingan Konseling di sekolah atau perguruan tinggi. Menurut Prayitno dalam Amirah program Bimbingan Konseling adalah satuan atau kecil rencana kegiatan layanan dan kegiatan pendukung bimbingan dan konseling yang dilaksanakan pada periode tertentu. Unsur-unsur dalam program Bimbingan Konseling salah satunya: (1) berdasarkan kebutuhan siswa, (2) jumlah dari peserta didik, (3) bidang bimbingan, (4) jenis layanan, (5) kegiatan pendukung, (6) volume kegiatan, (7) frekuensi layanan, (8) waktu kegiatan, (9) lama kegiatan dan (10) kegiatan khusus. Jadi evaluasi program bimbingan dan konseling adalah proses pemberian nilai pada suatu rencana kegitan yang telah dibuat dalam rangka mengambil keputusan.

Menurut buku “ Bimbingan dan Konseling di Sekolah” terbitan Direktorat Tenaga Kependidikan Direktorat Jenderal Peningkatan Mutu Pendidik dan Tenaga Kependidikan, Departemen Pendidikan Nasional dalam Anas ada dua macam aspek kegiatan penilaian program kegiatan bimbingan, yaitu penilaian proses dan penilaian hasil. Penilaian proses yang maksudkan untuk mengetahui sampai sejauh mana keefektifan layanan bimbingan dilihat dari prosesnya, sedangkan penilaian hasil yang dimaksudkan untuk memperoleh informasi keefektifan layanan bimbingan dilihat dari hasilnya. Aspek yang dinilai, baik proses maupun hasil antara lain:29 1) Kesesuaian antara program dan pelaksanaan. 2) Keterlaksanaan program. 3) Hambatan -hambatan yang dijumpai. 4) Dampak layanan bimbingan terhadap kegiatan belajar mengajar. 5) Respon siswa, personil sekolah, orang tua, dan masyarakat terhadap layanan bimbingan. 6) Perubahan kemajuan siswa dilihat dari pencapaian tujuan layanan bimbingan, pencapaian tugaas perkembangan-perkembangan dan hasil belajar, dan keberhasilan siswa setelah menamatkan sekolah, baik pada studi lanjutan maupun pada kehidupan di masyarakat.

\section{METODE PENELITIAN}

Penelitian ini merupakan penelitian kuantitatif. Metode yang digunakan dalam penelitian ini merupakan metode survey dengan menggunakan pendekatan korelasi, karena penelitian ini bertujuan untuk mengetahui ada atau tidaknya hubungan antar dua variabel, yakni keterampilan evaluasi dengan keterlaksanaan evaluasi program bimbingan dan konseling. Subyek pada penelitian ini adalah guru bk di SMA Negeri dan Swasta Se-Kecamatan Cilincing Kota Jakarta Utara dengan jumlah 30 guru bk yang tersebar pada 7 SMA Negeri dan 4 SMA Swasta Se-Kecamatan Cilincing. Teknik pengumpulan data yang digunakan dalam penelitian ini adalah angket dengan menggunakan skala Guttman dan data yang diperoleh dianalisis dengan menggunakan teknik korelasi product moment. 


\section{Jurnal Konseling Indonesia}

http://ejournal.unikama.ac.id/index.php/JKI

ISSN: Print 2475-888X - Online 2476-8901

Vol. 5 No. 1, Oktober 2019. hlm. 21 - 27

\section{HASIL}

Berdasarkan dari hasil analisis instrumen Keterampilan Evaluasi dan Keterlaksanaan Evaluasi Program Bimbingan dan Konseling Se-Kecamatan Cilincing Jakarta Utara (X), sebanyak 87 persen atau 26 guru bk di SMA Se-Kecamatan Cilincing Jakarta Utara Memiiki pengetahuan keilmuan bk yang baik dan dari 30 guru bk hanya 13 persen atau 4 guru bk yang memiliki keilmuan bk yang kurang baik. Berikut merupakan diagram persentase:

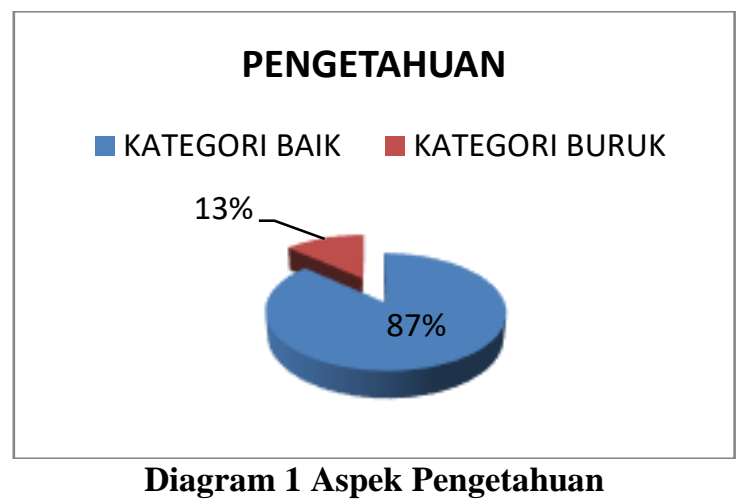

Akan tetapi, hasil tersebut berbeda ditunjukan oleh guru bk SMA Di Se-Kecamatan Cilincing Jakarta Utara yaitu pada aspek keterampilan teknis, karena tidak ada satupun guru bk yang memiliki keterampilan yang baik pada aspek perencanaan, pelaksanaan dan evaluasi hasil pada layanan yang telah diberikan. Hal tersebut dapat dilihat pada diagram berikut:

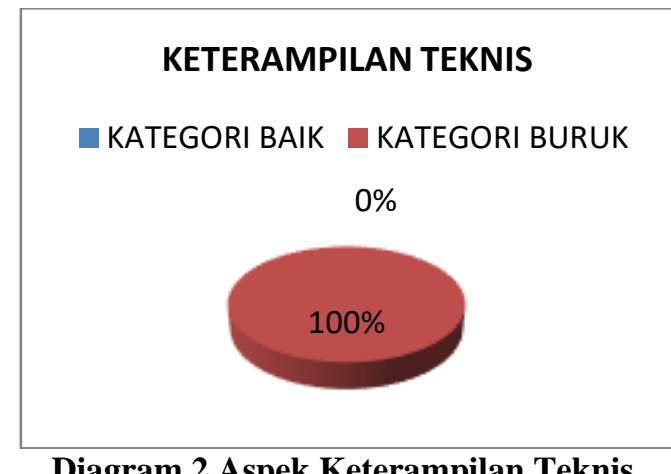

Diagram 2 Aspek Keterampilan Teknis.

Berdasarkan analisis instrumen Keterlaksanaan Evaluasi Program Bimbingan dan Konseling, menunjukan bahwa 63 persen atau 19 guru bk yang melaksanakan evaluasi pada program yang mereka laksanakan, dan hanya 37 persen atau 11 guru bk yang tidak melaksanakan evaluasi program bk. Berikut diagram keterlaksanaan evaluasi program bk:

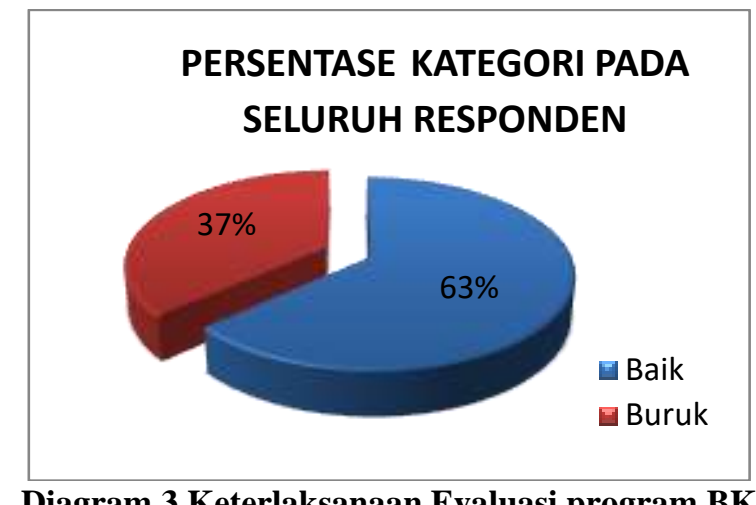

Diagram 3 Keterlaksanaan Evaluasi program BK 
Sedangkan berdasarkan aspek-aspek keterlaksanaan evaluasi program bimbingan dan konseling, 81 persen guru bk melaksanakan evaluasi pada aspek evaluasi proses program bimbingan, sementara sekitar 77 persen guru bk yang melakasanakan evaluasi pada aspek evaluasi hasil program bimbingan dan aspek evaluasi program bimbingan, sedangkan hanya 66 persen guru bk yang melaksanakan evaluasi pada aspek evaluasi perencanaan program. Hal tersebut dapat dilihat pada diagram berikut:

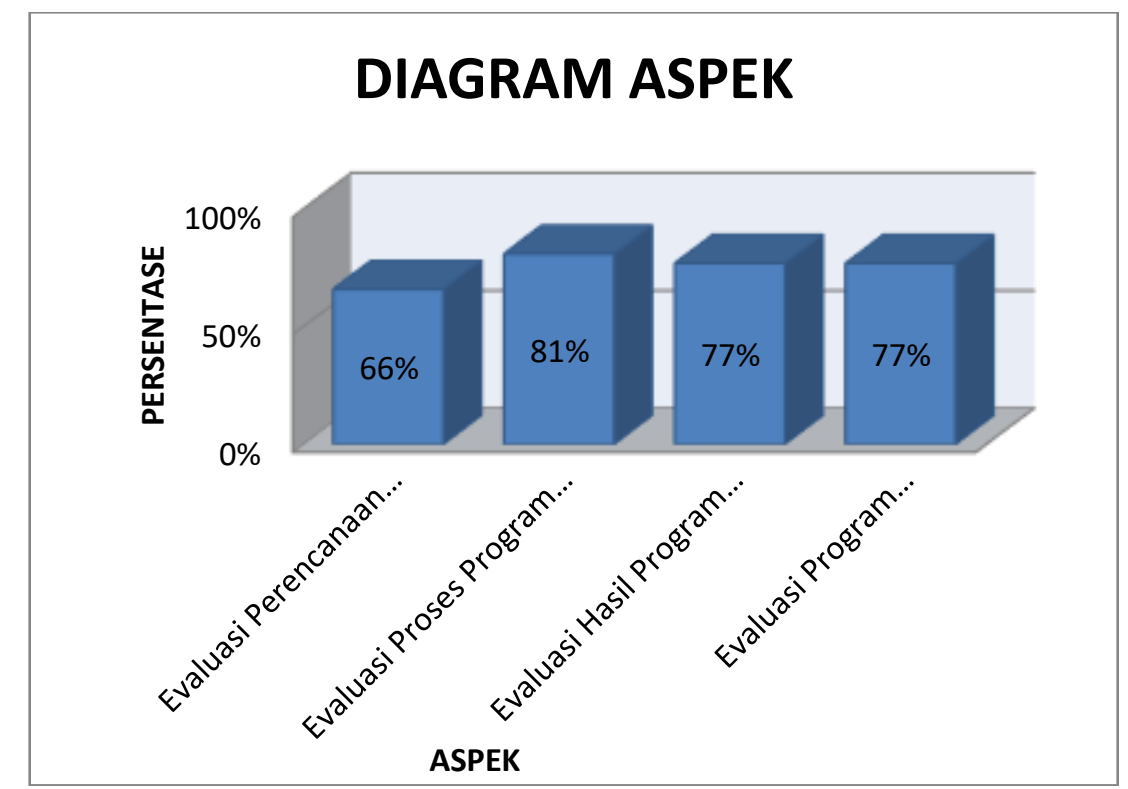

Diagram 4 Aspek-Aspek Keterlaksanaan Program Bimbingan dan Konseling.

Berdasarkan hasil uji korelasi Product Moment Pearson Teknik Parametric pada aspek Keterampilan Evaluasi Program Bimbingan (X) dan Keterlaksanaan Evaluasi Program Bimbingan (Y) memiliki hubungan yaitu r-hitung 0,643 lebih besar dari r-tabel 0,361 artinya Ha diterima dan $\mathrm{H}_{0}$ ditolak. Jadi, ada hubungan antara keterampilan melakukan evaluasi dengan pelaksanaan evaluasi disekolah. Berdasarkan hasil analisa data peneliti menyimpulkan bahwa guru BK SMA di kecamatan Cilincing Jakarta Utara memiliki keterampilan evaluasi yang baik dengan nilai rata-rata $75 \%$ sehingga konselor sekolah tersebut juga mampu melakukan pelaksanaan evaluasi dengan baik pula di sekolah mereka masing-masing.

\section{PEMBAHASAN}

Hasil penelitian serupa juga dikemukan oleh Badrujaman (2015) dalam penelitian Pengaruh Model Evaluasi Layanan Dasar Berorientasi Akuntabilitas Terhadap Peningkatan Akuntabilitas Guru Bk Smp di Jakarta Timur mengemukakan bahwa keterampilan evaluasi berkontribusi signifikan terhadap keterlaksanaan evaluasi dengan pengujian hipoetsis, diketahui nilai $\mathrm{t}=3,09$ lebih besar dari t table (pada taraf siginikansi $\alpha=0,05$ dan derajat kebebasan = 31) $1,697<3,09$, maka H0 ditolak dan koefisien korelasi signifikan.

Dalam menyimpulkan hasil keterlaksanaan program disekolah SMA di kecamatan Cilincing Jakarta Utara, peneliti juga merujuk pada table klasifikasi standar penilaian dalam melakukan evaluasi program konseling dari Guidelines for Performance Based Professional School Counselor Evaluation (Missouri Department of Elementary and Secondary Education, 2000, dalam Saputra, 182:2015) yaitu:

\begin{tabular}{|l|l|l|}
\hline No & \multicolumn{1}{|c|}{ Kriteria } & \multicolumn{1}{c|}{ Keterangan } \\
\hline 1. & Terlaksana $78-100 \%$ & Sesuai dengan standar \\
\hline 2. & Terlaksana $66-77 \%$ & Mendekati standar \\
\hline 3. & Terlaksana $\leq 65 \%$ & Jauh dari standar \\
\hline
\end{tabular}

Tabel 1 Kriteria Standar Penilaian 
Berdasarkan table tersebut terdapat persamaan bahwa keterlaksanaan program BK disekolah tersebut termasuk dalam kategori baik dengan maksud mendekati standar dengan persentase $75 \%$. Artinya, guru BK disekolah tersebut telah terampil dalam melaksanakan evaluasi pada program-program konseling yang telah mereka laksanakan walaupun keterampilan yang mereka miliki sangat rendah.

Akan tetapi hasil penelitian yang dikemukakan oleh peneliti bertolak belakang jika dibandikan dengan hasil penelitian terdahulu yang dilakukan oleh Saputra (2015) dalam penelitian Evaluasi Program Konseling Di Smp Kota Malang menggunakan evaluasi Discrepancy Model yaitu program konseling di SMP Kota Malang masih jauh dari standar dengan persentase hanya 51,1\% aspek kegiatan program konseling telah terlaksana dengan baik. Selanjutnya, di SMP tersebut setidaknya terdapat $17,8 \%$ aspek kegiatan program konseling yang hanya terlaksana sebagaian. Sedangkan untuk program konseling yang tidak terlaksana sama sekali di SMP tersebut adalah $31,1 \%$ dan terdapat beberapa kegiatan yang tidak bisa dilaksanakan konselor dengan baik yaitu evaluasi hasil program konseling, pemanfaatan teknologi dalam konseling, dan pembuatan agenda yang jelas. (Saputra, 2015:183).

Hasil penelitian ini juga berbeda dengan penelitian yang dilakukan oleh (Rachmalia 2006, dalam Badrujaman, 2015) mengenai pelaksanaan tugas pokok guru BK di kecamatan Cempaka Putih Jakarta Pusat mengemukakan bahwa aspek evaluasi program bimbingan dan konseling masih belum banyak dilakukan. Guru BK yang menjawab selalu melakukan evaluasi layanan untuk mengetahui seberapa sukses layanan yang diberikan sebanyak $18.75 \%$, guru BK yang menjawab sering $25 \%$, sedangkan $50 \%$ menjawab kadang-kadang, dan $6.25 \%$ menjawab pernah, dan penelitian yang dialkukan oleh (Muryani 2008, dalam Badrujaman, 2015) menunjukan bahwa kualitas pelaksanaan evaluasi BK pada SMA di Kecamatan Kembangan Jakarta Barat masih rendah dilakukan yaitu 21.01\% (pencapaian maksimum $=100 \%$ ). (Badrujaman, 2015).

Namun, peneliti juga menemukan kejanggalan yaitu seluruh guru BK SMA di kecamatan Cilincing Jakarta Utara memiliki tingkat keterampilan evaluasi rendah, namun mereka mampu melaksanakan pelaksanaan evaluasi dengan baik. Ada beberapa alasan yang ditemukan, yaitu: (1) Pemahaman Guru BK mengenai keterampilan evaluasi dalam mengelola program BK mempunyai dampak yang tidak baik dikarenakan kurangnya adminitrasi evaluasi yang dilakukan dan terdokumentasi dengan baik. (2) Pemahaman dan keterlaksanaan evaluasi yang dilakukan oleh guru BK sangat baik akan tetapi dalam evaluasi keterampilan buruk sebab banyaknya beban kerja yang diterima menjadi hambatan. (3) Persepsi guru bk dalam menjalankan keterampilan evaluasi sangat berat dan membutuhkan waktu yang sangat lama dalam hal menganalisis keterlaksanaan program BK.

\section{PENUTUP}

Berdasarkan pembahasan mengenai hasil penelitian, maka dapat diidentifikasikan beberapa kesimpulan penelitian, meliputi: Dari hasil uji hipotesis, menemukan bahwa terdapat hubungan antara keterampilan evaluasi program dengan keterlaksanaan evaluasi program bimbingan dan konseling. Akan tetapi, dari hasil analisis data, peneliti memiliki kejanggalan antara keterampilan evaluasi dengan keterlaksanaan evaluasi. Dikarenakan dari hasil yang didapatkan, keterampilan evaluasi memiliki nilai terendah daripada keterlaksanaan evaluasi. Terdapat beberapa faktor yang menyebabkan keterampilan lebih rendah daripada keterlaksanaan, yaitu: (1) Pemahaman Guru BK mengenai keterampilan evaluasi dalam mengelola program BK mempunyai dampak yang tidak baik dikarenakan kurangnya adminitrasi evaluasi yang dilakukan dan terdokumentasi dengan baik. (2) Pemahaman dan keterlaksanaan evaluasi yang dilakukan oleh guru BK sangat baik akan tetapi dalam evaluasi keterampilan buruk sebab banyaknya beban kerja yang diterima menjadi hambatan. (3) Persepsi guru bk dalam menjalankan keterampilan evaluasi sangat berat dan membutuhkan waktu yang sangat lama dalam hal menganalisis keterlaksanaan program BK.

\section{DAFTAR RUJUKAN}

Ananda, R., \& Ratida, T.(2017). Pengantar Evaluasi Program Pendidikan. Perdana Publishing.

Anni, C. T. (2011). Need Assesment Model Penyusunan Program Bimbingan Dan Konseling Bidang Bimbingan Belajar Berbantuan Sistem Informasi Manajemen Di Sma Negeri Kota Semarang. Jumal Unnes.

Badrujaman, A. (2011). Teori dan Aplikasi Evaluasi Program Bimbingan konseling. Jakarta: Indeks.

Badrujaman, A., Furqon, Yusuf, S., \& Suherman(2011). Penganuh Model Evaluasi Layanan Dasar Berorientasi Akuntabilitas Terhadap Peningkatan Akuntabilitas Guru BK SMP. Jumal Parameter, 158.

Faricha Azizah, H. F. (2017). Evaluasi Pelaksanaan Program Layanan Bimbingan Dan Konseling Di Sekolah . Prosiding Seminar Bimbingan dan Konseling . 
Gendom, B. (2011). Pengembangan Instrumen Asesmen Kebutuhan Perkembangan Untuk Penyusunan Kurikulum dan Evaluasi Program BK. Jurnal Bimbingan dan Konseling, 1-8.

Mashudi, F. (2015). Pedoman Lengkap Evaluasi \& Supervisi Bimbingan Konseling. Yogyakarta: Diva Press.

Nirwana. (2016). Evaluasi program kerja Bimbingan Konseling di MAN2 Model Makassar. Jumal Bimbingan dan Konseling , 20-28.

Putra, E., \& Nusantoro, E. (2015). Evaluasi pelaksanaan konseling pada SMK 1 Blora model CCIP. Jumal Unnes, 37-39.

Putra, W. N. (2015). Model, Evaluasi Program Konseling Di Smp Kota Malang: Discrepancy. Jumal Psikologi Pendidikan \& Konseling.

Rahman, F. (2012). Modul Ajar Pengembangan dan Evalauasi Program BK. Jumal Uny.

Syamsu, Y.(2006). Program Bimbingan dan Konseling SLTP dan SLTA. Bandung: Pustaka Bani Quraisy. 